\title{
KEY DRIVERS IN LIFECYCLE OF CZECH MACHINERY CLUSTER
}

\section{HLA VNÍ HNACÍ SÍLY V GIVOTNÍM CYKLU STROJÍRENSKÉHO KLASTRU}

\section{PROF. ING. KAREL SKOKAN, PH.D.}

\author{
\begin{tabular}{l|l} 
Ústav doktorských studii & Institute of doctoral studies
\end{tabular} \\ Obchodn Пpodnikatelská fakulta v Karviné School of Business Administration in Karvina \\ Slezská univerzita v Opav $\mid$ Silesian University in Opava \\ $\bowtie$ Univerzitní nám. 1934/3 73340 Karviná, Czech Republic \\ E-mail: skokan@opf.slu.cz.
}

\begin{abstract}
Annotation
Regional industry clusters as specific form of networked organisations in a given industry and territory have become very popular tools of regional and economic policies mainly in the last decades. In the Czech Republic their support is connected mainly with the EU structural funds since 2004. Clusters like many other entities come through their lifecycle and exhibit different development phases of their development which are triggered by various factors and events. The objective of the paper is to identify the main drivers which played the decisive role in the development of machinery cluster based in Moravia Silesia region of the Czech Republic. Research methodology is based on results of semi-structured interviews with regional key players accompanied by analysis of time series data on cluster initiative development derived from cluster member's annual reports. The paper concludes there are both exogenous and endogenous factors and policies at regional and national levels which play important role in cluster formation but at first still holds clusters are business driven.
\end{abstract}

\section{Key words}

cluster lifecycle, main drivers, machinery

\section{Anotace}

Regionální prTmyslové klastry jako specifická forma síŠvé organizace v konkrétním odv \ví a území se staly velmi populárním nástrojem regionální a hospodáŚké politiky zejména $v$ posledních desetiletích a $v$ Leské republice je jejich podpora spojena od roku 2014 zejména se strukturálními fondy EU. Klastry podobn jjako mnoho dalğ́ch entit procházejí svým ğvotním cyklem a vykazují rTzné vývojové fáze, které jsou spouğĐny konkrétními faktory a událostmi. Cílem llánku je identifikovat hlavní hnací síly, které sehrály rozhodujicí roli pŚ formování strojírenského klastru $v$ Moravskoslezském regionu v Leské republice. Metodika výzkumu vychází z výsledk丁 semistrukturovaných rozhovorTs regionálními pŚedstaviteli a zástupci firem v klastru dopln nhá o ḷasové

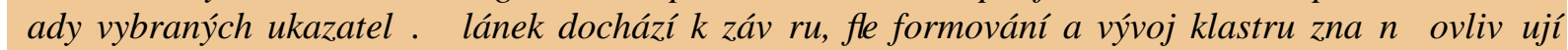
endogenní a exogenní vlivy a zásahy národní i regionální politiky, avg்ak klị ovou roli sehrává podnikatelský pŚstup jeho l̦ lenT.

\section{Klị́ ová slova}

ǵvotní cyklus, hlavní hnací síly, strojírenství

JEL classification: L6, O25, RI 


\section{Introduction}

Theories of regional development and regional policies cover two principal issues of regional disparities and regional performance or competitiveness. Regional disparities are examined in different ways to find solution for proper instruments of regional policy (Viturka, 2011) which can contribute to the solution of regional problems. In current approaches to finding the ways for the growth of competitiveness very often innovation, innovation infrastructure and business clusters are mentioned.

Innovations are generally considered a key factor of the socio-economic development and important tool for productivity increase and growth of added value (G̣ítek, Klímová, 2012). By Klímová (2013) innovation infrastructure (under which we mean business incubators, science and technology parks, research centres, etc.) contributes to creation and diffusion of new knowledge, helps to cooperation of science and business sphere and technology transfer and supports innovation enterprise.

In regional and economic policy the term Ăclusterñ is usually used to explain geographical concentrations of economic and innovation activities which are organized and managed to achieve pre-defined goals and objectives connected mainly with achievement of higher productivity of companies and higher competitiveness. During last decades clusters gained more importance as an element of regional economic development and innovation strategies in EU member states (Skokan, Poledníková, 2011). The modern ages of clusters is closely connected with Michael Porter who described in his work Competitive advantage of nations the tight relationship between cluster participation and the competitiveness of firms and industries and proposed the first cluster definition, very often criticized and improved later by many authors (Porter 2003). By him clusters are geographic concentrations of interrelated companies, specialized suppliers, etc. in similar sector as well as related institutions. Porter's theory of clusters has become the standard concept and was further elaborated by many followers. Clusters are usually managed by cluster organizations and are connected with cluster initiatives defined by Lindqvist (2013) as organized efforts to increase the growth and competitiveness of clusters within a region, involving cluster firms, government and/or the research community.

Clusters are expected to bring benefit not only to their business members but to the regions they operate in and to universities as well. Firms in clusters can be more specialized and can better cooperate than in isolation. They can also reach the higher level of innovation due to the knowledge spill-over in a proximity, clusters also stimulate the new start-ups, etc. Cluster activities cover many joint actions in areas of networking, human resources and training, research and development, marketing, internationalization, financing and others (Blazek, Kuncová, 2011).

Clusters are not created from scratch but they develop gradually and they have their lifecycle. Cluster evolution theory mainly deals with the emergence and the development of clusters. Evolutionary approaches emphasize the unpredictability of future cluster trajectories but stress that they are constrained by the past. Menzel and Fornahl (2010) propose the concept of cluster life cycles, a concept that is derived from product- and industry life cycle approaches. The authors expect clusters to move through a set of stages (emergence, growth, sustainment and maturity, decline or transformation) all of which feature different factors that are relevant for cluster development.

Emerging clusters are usually difficult to identify because potential firms that might be part of a cluster are scattered and the spatial and thematic boundaries are not yet defined (Menzel and Fornahl, 2010). The distinguished feature for cluster formation is the role of pre-existing economic, political and institutional structures and the role of pioneering firms in particular regions. Firms are considered to be attracted by the proximity to higher educational institutes and a pool of well-educated labour. Growing clusters on the other hand are increasingly affected by demand and competition. With regard to sustaining clusters the predominance of incremental innovations point to an increasing maturity of the cluster. Also, the number of market entrants and the number of collaborations with higher education institutes decline and clusters lock in (Rehak et al., 2013). Declining clusters exhibit rigid 
and homogeneous networks slowing down the innovation process. Cluster transformation and renewal requires radical innovations, a change of the institutional setup, and networks, financial resources, proximity to research institutions and a pool of skilled labour. These factors obviously resemble factors that have been decisive for cluster emergence. The following sections analyse the main factors that are relevant for cluster change.

\section{Objectives and Methods}

The paper deals with the main factors which influenced the development of machinery and engineering industries in old traditional region of Moravia Silesia in the Czech Republic. The restructuring of the region after 2000 is marked by huge inflow of foreign direct investment and by the development of clusters in traditional industries such as engineering and wood industry and also in new industries the most important being automotive, ICT and new energy sources. In fact, already before 1989 under communist regime the main metallurgical, mining and heavy industries were clustered in the region with their headquarters, main suppliers and also with a specific VG̈B-Technical University offering the education at faculties of mining, engineering, metallurgy and business and economics. Many ñ́traditionalò companies in machinery industry which were established tens of years ago were transformed during privatization, however this tradition and entrepreneurial spirit in industry were important for organizing the cluster initiative which lead to establishment of engineering and machinery cluster.

The main objective of the paper is to identify the main endogenous and exogenous drivers from the view of the region which played the decisive role in the development of machinery cluster based in Moravia Silesia region of the Czech Republic. Research strategy is based on researcher's own experience in region, the results of semi-structured interviews with key regional players in Regional administration, Regional development agency, academics and managers of important firms. The subsidiary objective is to show the basic characteristics of recent machinery cluster development under the heading of Czech machinery cluster using time series data on cluster initiative development derived from cluster member's annual reports in the period 2005 ï 2012 (later data are not available yet).

\section{Main drivers in the development of machinery and engineering industry in Moravia Silesia}

Current level and state of the art of regional machinery and engineering industry is the outcome of previous development of metallurgy and engineering. The main stages understood from the view of cluster lifecycle concepts are described in Table 1.

Tab. 1: Main phases of industry lifecycle in machinery and engineering of Moravia Silesia

\begin{tabular}{|c|c|c|c|}
\hline Emergence Phase & Growth Phase & Sustainment Phase & Transformation Phase \\
\hline $\begin{array}{l}\text { Prior industry } \\
\text { structure } \\
\text { Entrepreneurial } \\
\text { environment } \\
\text { Pool of labour }\end{array}$ & $\begin{array}{l}\text { Demand increase } \\
\text { Supportive } \\
\text { institutions and } \\
\text { organisations } \\
\text { Suppliers and } \\
\text { customers } \\
\end{array}$ & $\begin{array}{l}\text { Growing inflexibility } \\
\text { of institutional } \\
\text { structures } \\
\text { Isolation and lock in } \\
\text { Loss of markets }\end{array}$ & $\begin{array}{l}\text { Change of political and } \\
\text { entrepreneurial environment } \\
\text { Change of cognitive } \\
\text { framework and firm routines }\end{array}$ \\
\hline $\begin{array}{l}\text { Phase 1: } \\
\text { Emergence of coal } \\
\text { mining, metal, heavy } \\
\text { machinery in the } 19^{\text {th }} \\
\text { century } \\
\text { (until 1918) }\end{array}$ & $\begin{array}{l}\text { Phase 2: } \\
\text { Gradual growth and } \\
\text { maturity } \\
\text { Breakdown due to } \\
\text { crisis and war } \\
\text { (1918 I 1945) }\end{array}$ & $\begin{array}{l}\text { Phase 3: } \\
\text { Maturity and decline of } \\
\text { large state owned } \\
\text { companies in planned } \\
\text { economy } \\
(1945-1989)\end{array}$ & $\begin{array}{l}\text { Phase 4: } \\
\text { Restructuring and dynamic } \\
\text { re-growth by privatisation } \\
\text { and FDIs establishment of } \\
\text { cluster initiative } \\
(1989-2013)\end{array}$ \\
\hline
\end{tabular}

Source: own processing 
Emergence phase is connected with the beginnings of coal mining in the region, the foundation of first ironworks in Ostrava (Vítkovice company in 1828), fast growth of metallurgy, heavy machinery and engineering. After establishment of Czechoslovakia in 1918 the region became national industrial centre and we can speak of growth phase. Market economy developed until 1939. These favourite conditions were interrupted by world crisis and Nazis occupation in 1939 ï 1945, however fast growing demand for the support of Germany in world war contributed to modernization and performance of machinery industry.

Post war development was characterized by nationalization (1945), concentration (1955-1970) of smaller firms into so called production-economic complexes similar to today's clusters. The main complexes in the region were e.g. Vítkovice metal-machinery complex, Steel and iron complex, Ostrava-Karviná mining group within which machinery companies were included and other enterprises. The growth was supported by state investment and Comecon division of labour for communist countries at one hand, on the other hand centrally planned economy, isolation from world and contemporary know-how and iron curtain lead to the loss of industrial dynamics in the $80^{\text {th }}$, which resulted in sustainment phase of machinery and engineering industry.

Transformation phase began after 1989 and at first included privatisation of companies with different outcomes depending on method $\ddot{i}$ voucher privatisation and direct management buy-out or foreign buy-out. It resulted in vertical disintegration of former complexes and big companies, establishment of new companies spinned-off from former parts of complexes. Attraction of FDIs and acquisitions, again lead to new firms establishment. Growth of productivity and employment due to modernization of production equipment, ICT, methods of management and focus to new markets in the EU and operating globally was the response to these changes which resulted in the establishment of Moravian Silesian engineering cluster initiative. After first years of fuzzy existence this first Czech cluster expanded outside the region and now covers national-wide located companies in main value chains operating under the heading of Czech machinery cluster. The main endogenous and exogenous drivers in the industry development during lifecycle from the view of region are summarized in Table 2.

\section{Tab.2: Endogenous and exogenous drivers of machinery cluster development}

\begin{tabular}{|l|l|l|}
\hline $\begin{array}{l}\text { Development } \\
\text { phase }\end{array}$ & Endogenous drivers \\
\hline $\begin{array}{l}\text { Ehase 1 } \\
\text { Emergence }\end{array}$ & $\begin{array}{l}\text { Presence of coal, related manufacturers and } \\
\text { supportive industrial structure (mining, } \\
\text { metallurgy and power production) in the } \\
\text { region. Location of region in the } \\
\text { neighbourhood of Poland and Slovakia. Good } \\
\text { traffic connection outside the region mainly } \\
\text { by rails. }\end{array}$ & $\begin{array}{l}\text { The expansion of industrialization in } \\
\text { Central Europe and demand for steel. } \\
\text { The development of civil engineering, } \\
\text { growing demand for machinery. } \\
\text { Developing European market. }\end{array}$ \\
\hline $\begin{array}{l}\text { Phase 2 } \\
\text { Gradual growth }\end{array}$ & $\begin{array}{l}\text { Knowledge accumulation and growing local } \\
\text { market demand, Established industrial basis } \\
\text { and structure in the region with a long } \\
\text { tradition. }\end{array}$ & $\begin{array}{l}\text { Economic recovery after world crises } \\
\text { (1929-1933), war impact since 1939, } \\
\text { demand of Germany, deliveries for the } \\
\text { German army. }\end{array}$ \\
\hline $\begin{array}{l}\text { Phase 3 } \\
\text { Sustainment }\end{array}$ & $\begin{array}{l}\text { Location of VSB Technical University } \\
\text { covering faculties of mining, metallurgy, } \\
\text { engineering, later electrical engineering. } \\
\text { Foundation of New metallurgical plant in } \\
\text { Ostrava and others and demand for machinery } \\
\text { products, establishment of research institutes } \\
\text { in the region. }\end{array}$ & $\begin{array}{l}\text { Communist centrally planned economy } \\
\text { and spatial division of labour ï huge } \\
\text { state investment into metallurgy and } \\
\text { machinery, state support and demand for } \\
\text { export to COMECON countries. }\end{array}$ \\
\hline
\end{tabular}




\begin{tabular}{|l|l|l|}
\hline $\begin{array}{l}\text { Development } \\
\text { phase }\end{array}$ & Endogenous drivers & Exogenous drivers \\
\hline $\begin{array}{l}\text { Phase 4 } \\
\text { Transformation }\end{array}$ & $\begin{array}{l}\text { Establishment of self-governing region } \\
\text { Moravia Silesia. Presence of semi-skilled } \\
\text { labour force. Expansion of Universities in the } \\
\text { region and growth of skilled academic staff. } \\
\text { Learning by doing and by interacting. First } \\
\text { regional development strategies. Re-directing } \\
\text { exports from East to the West. } \\
\text { Modernization of production equipment in } \\
\text { privatized and new established companies. }\end{array}$ & $\begin{array}{l}\text { Transformation of economy and } \\
\text { restructuring of regional economy by } \\
\text { strategy ï attraction of FDIs. Accession } \\
\text { to European Union. Impact of world } \\
\text { crisis. Political instability in the Czech } \\
\text { Republic, lack of national economic } \\
\text { strategies, unclear governmental policies. } \\
\text { improve the position of regional economy. }\end{array}$ \\
\hline
\end{tabular}

Source: own processing

\section{Development of Czech Machinery Cluster initiative}

The leader in implementing cluster initiatives in the Czech Republic has become Moravian-Silesian Region, an old industrial region which restructuring after 2000 is marked by huge inflow of foreign direct investment and by the development of clusters in traditional industries such as machinery and wood industry and also in new industries of which the most important being automotive, ICT and new energy sources. As follows from the previous analysis the machinery and engineering basis of so called anchor firms for machinery cluster was created in the last century and the linkages among them were already set up in the past and only the processes of transformation and privatisation interrupted and restructured them. In fact, already before 1989 under communist regime the main metallurgical, mining and heavy industries were clustered in the region with their headquarters, main suppliers and also with a specific VGB-Technical University offering the education at faculties of mining, engineering, metallurgy, electrical engineering and informatics and business and economics.

The new era of clusters development started in the region as a joint initiative of Czech Investment agency CzechInvest and VSB-Technical University of Ostrava supported by the Moravian Silesian Regional Authority. The region was the first Czech region to carry out a study identifying clusters (2002), and then established the first cluster in the country $\ddot{i}$ the Moravian-Silesian Engineering Cluster (2003) which was later transformed into national Czech machinery cluster. Main stages and events of this development which was strongly influenced and supported by regional authorities and by the financial aid from EU Structural funds are given in Table 3.

Tab. 3: Main events affecting cluster development in Moravia Silesia

\begin{tabular}{|l|l|}
\hline Year & Action \\
\hline 2002 & $\begin{array}{l}\text { Pilot project ñIdentification of industry grouping for state aid support in North Moravia } \\
\text { Silesiaò }\end{array}$ \\
\hline 2003 & Establishment of first Czech cluster ñMoravian Silesian Engineering clusterc̀ \\
\hline $2004 i ̈ 2005$ & Search for clusters in Moravia-Silesia (identification phase) \\
\hline 2006 & Regional initiative ClusterNet in Morava-Silesia \\
\hline 2005 ï 2008 & Establishment of eight regional clusters in Moravia Silesia (CLUSTER Programme) \\
\hline 2008 & Czech National Cluster Association \\
\hline $2009 i ̈ ~ 2014$ & Development of established regional clusters (COOPERATION Programme) \\
\hline
\end{tabular}

Source: Own processing

In the Pilot study (see Table 3) the metal-engineering cluster was identified as the cluster of highest potential in the region. The establishment of cluster was initiated at the regional level by Union for the Development of the Moravian Silesian Region with additional support of Moravian Silesian Regional Administration, and VGB-Technical University of Ostrava (VG̈-TU) which is also the member of the majority of MS clusters. 
Originally cluster was designed as a horizontal platform for the whole engineering sector in the region with a tendency to quit metallurgy and heavy machinery in the future. These broad objectives, weak management under the head of Union for the Development of the Moravian Silesian region and unclear financing of its activities lead to crisis in financing, concept, specialisation and membership, when the member base turned down from 35 to 18 members in two years. The strong impetus for cluster development came in 2005 when the leadership took over the leading machinery company in the region, Vítkovice machinery group.

The main activities of cluster are focused to supply chains $\ddot{i}$ enabling smaller cluster members to participate in big contracts for power industry, nuclear power and ecological engineering; purchase alliances - cost reduction of joint purchasing based on quantity discounts; internalisation through export and investment; cooperative projects in innovation and training engineers for nuclear power; energy resources of the 21st century; innovation in professional training at secondary schools; HRD for R\&D teams, new talents for science and research. What is important, all these outcomes stem from business and requests from companies and not from public sphere, they are business driven.

The development of pilot Czech cluster was not straightforward and is documented at Figure1 where the time series of number of cluster firms and total clusters values for turnover and value added are depicted.

Fig. 1: Demonstration of Machinery cluster development

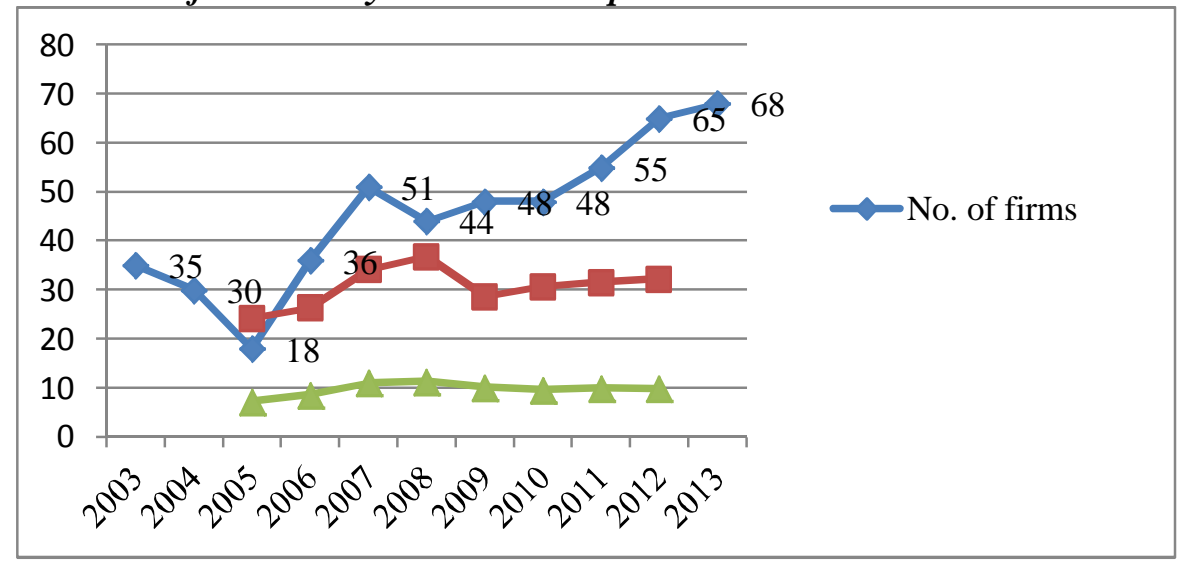

Source: Own processing

The gradual growth of number of cluster firms is based on value chain related companies and was interrupted in the years of financial crises. Surprisingly the volume of sales and total value added of cluster companies did not followed the growing trend of cluster members as not all new member are manufacturing firms with their own production.

\section{Conclusion}

Establishment of clusters in the Czech Republic became very fashionable in the last decades and was driven mainly by the availability of EU structural funds which financed feasibility studies for their identification and supported their projects after co called cluster establishment. The emergence of clusters takes many forms. One example is based on companies which are already located in industry and the region for many years. This is the case of machinery cluster in Moravia Silesia region. Another example follows from coming or establishment of new firms in industry and regions, this is the case of ICT or new energy sources clusters where the firms are young. However in both cases it must be the firms which are established and operate in given industry and region at first, gradually develop the linkages and networks and pass through various phases of their lifecycle. The existence of these firms is the fundamental condition for cluster development. The issue is if we call them industry groupings or clusters depending on the existence of cluster initiatives and cluster organization. 
In majority of clusters their member firms existed and cooperated within industry and the region before cluster initiative was organized and declared. There are many drivers, events or policy measures of endogenous and exogenous nature at regional, national and global levels which have strong influence upon industry and cluster lifecycle. They affect the level of performance and competitiveness of companies both in industry and cluster. The paper identified main these factors and drivers in machinery and engineering industry in Moravia Silesia region which played decisive role in this industry and cluster development during their lifecycle in old industrial region. The case of Czech machinery cluster showed the creation of cluster initiative does not guarantee the future cluster success without involvement of key business players. Clusters were originally defined in theory as industry driven and this fact still holds even under specific Czech conditions regardless the cluster funding.

\section{Literature}

[1] BLAG̣EK, J., KUNCOVÁ, I., (2011,). Clusters: Fashionable Term or a Real Source of Competitiveness? Ekonomický !asopis, vol. 59, iss. 3, pp. 225-242. ISSN 0013-3035.

[2] KLÍMOVÂ, V., (2013). Innovation infrastructure in Moravian regions. In 16th International Colloquium on Regional Sciences. Conference Proceedings. Brno: Masarykova univerzita. ISBN 978-80-210-6257-3. DOI 10.5817/CZ.MUNI.P210-6257-2013-24. DOI 10.5817/CZ.MUNI.P210-6257-2013-24.

[3] LINDQVIST, G., KETELS, C., SÖLVELL, Ö., (2013). The Cluster Initiative Greenbook 2.0. Stockholm: Ivory Tower AB. ISBN 978-91-974783-5-9.

[4] MENZEL, M. P., FORNAHL, D. (2010). Cluster life cycles ï dimensions and rationales of cluster evolution. Industrial and Corporate Change, vol. 19, iss. 1, pp. 205-238. ISSN 0960-6491. DOI 10.1093/icc/dtp036.

[5] PORTER, M. E., (2003). The Economic Performance of Regions. Regional Studies, vol. 37, iss. 6-7, pp. 549-578. DOI 10.1080/0034340032000.108688.

[6] REHAK, S. HUDEC. O, BUCEK, M., (2013). Path dependency and path plasticity in emerging industries Two cases from Slovakia. Zeitschrift fur Wirtschaftsgeographie, vol. 57, iss. 1-2, pp. 52-66, ISSN 00443751.

[7] SKOKAN, K.; POLEDNÍKOVÁ, E., (2011). Public Aid for Clustering Firms in the Czech Regions. In Finance and the performance of firms in science, education, and practice. Proceedings of the 5th International Scientific Conference. Zlín: TomáġBaŠa Univerzity. pp. 423-432. ISBN 978-80-7454-020-2.

[8] VITURKA, M., Ǵ̣TEK, V., KLÍMOVÁ, V., TONEV, P., (2011). Application of Microeconomic and Macroeconomic Ápproach to Evaluating Disparities in the Regional development. Ekonomický ! asopis, vol. 59, iss. 7, pp. 71-90. ISSN 0013-3035.

[9] G̦TEK, V., KLÍMOVÁ, V., (2012). Non-technological innovations as a criterion for definition of innovative firm. In 15th International Colloquium on Regional Sciences. Conference Proceedings. Brno: Masarykova univerzita. pp. 331-341. ISBN 978-80-210-5875-0.

This article was supported by Eurocores GALR project CRP/11/E025 titled Cluster life cycles ï the role of actors, networks and institutions in emerging, growing, declining and renewing clusters. 